\title{
ANALISIS PERUBAHAN KONDISI SOSIAL-EKONOMI MASYARAKAT BLOK PEKAUMAN DESA ASTANA DENGAN KEBERADAAN TRADISI ZIARAH MAKAM SUNAN GUNUNG JATI DI CIREBON
}

\author{
Noeranisa Adhadianty Gunawan, Yadi Ruyadi, Mirna Nur Alia A \\ Universitas Pendidikan Indonesia \\ Jl. Dr.Setiabudi 229 Bandung 40154, Jawa Barat, Indonesia \\ Email: noeranisaicha@gmail.com
}

\begin{abstract}
Abstrak Penelitian ini dilakukan pada masyarakat Blok Pekauman Desa Astana dengan keberadaan Makam Sunan Gunung Jati di Cirebon yang telah menyebabkan perubahan sosial-ekonomi pada masyarakat. Makam Sunan Gunung Jati telah lama dikenal masyarakat sebagai tempat untuk melakukan praktik ziarah. Sehingga mengundang banyak masyarakat dari seluruh daerah, khususnya di Pulau Jawa yang datang sebagai peziarah untuk berdoa di Makam Sunan Gunung Jati. Dengan banyaknya peziarah yang datang tersebut menyebabkan perubahan dalam kehidupan sosial-ekonomi masyarakat Blok Pekauman yang berada di komplek pemakaman Sunan Gunung Jati. Metode penelitian yang digunakan adalah metode deskriptif dengan pendekatan penelitian metode campuran. Teknik pengumpulan data dilakukan dengan angket, observasi partisipatif, wawancara mendalam, studi dokumentasi, dan studi litelatur. Temuan hasil penelitian terdiri dari temuan hasil kuantitatif dan temuan hasil kualitatif. Hasil temuan kuantitatif mencakup statistika deskriptif yang menuangkan pertanyaan angket dalam presentase. Sedangkan temuan hasil penelitian kualitatif merupakan gambaran sosial-ekonomi masyarakat blok Pekauman Desa Astana mencakup aspek pendidikan yang sudah baik, intensitas pertemuan dan kegiatan masyarakat yang kadang-kadang dan sering dilakukan, keberadaan peziarah yang menimbulkan dampak positif, ritual-ritual dalam praktik ziarah masih dilaksanakan, perekonomian masyarakat sudah baik dan lingkungan hidup sudah bersih.

Kata kunci: kondisi sosial-ekonomi, masyarakat, perubahan, tradisi, ziarah
\end{abstract}

\section{PENDAHULUAN}

Dalam kehidupan yang semakin modern ini, menyebabkan seluruh masyarakat berlomba-lomba untuk berupaya untuk mensejahterakan kehidupannya, sehingga dapat memenuhi kebutuhan sehari-hari. Hal tersebut membuat masyarakat mencari berbagai peluang agar mendapatkan kehidupan yang lebih baik. Peluang tersebut dimanfaatkan oleh masyarakat dengan sebaikbaiknya. Sehingga peluang sekecil apapun akan masyarakat manfaatkan selama memberikan keuntungan. Sama halnya seperti pada masyarakat Blok Pekauman Desa Astana Kabupaten Cirebon yang memanfaatkan keberadaan makam Sunan Gunung Jati sebagai tradisi ziarah yang memang sudah dijalankan masyarakat Cirebon sejak berpuluh-puluh tahun yang lalu. Keberadaan makam Sunan Gunung Jati tersebut memberikan peluang yang besar, sehingga terlihat banyaknya pedagang yang berjualan di sekitar komplek makam. Sunan Gunung Jati atau Syarif Hidayatullah merupakan
Wali Allah yang dikenal sebagai satu-satunya penyebar Agama Islam di Jawa Barat. Nidallah (2011, hlm. 9) mengungkapkan bahwa "beliau adalah peletak dasar aqidah Islamiyah yang menjadi kepribadian masyarakat Cirebon". Sehingga, bagi masyarakat Cirebon, beliau merupakan penyebar agama Islam yang mengayomi dan membimbing masyarakat sehingga ajaran Islam tersebut diterapkan dalam kehidupan sebagai cerminan perilaku dan kepribadian masyarakat. Wali Allah tersebut diberikan julukan oleh masyarakat sebagai Wali Songo yang berjumlah 9 orang yang tersebar di Pulau Jawa. Beliau merupakan sosok yang sangat dihormati dan disegani oleh masyarakat karena kewibawaan, kharisma, serta tindakannya yang mencerminkan ketaatan dari seorang Wali. Seperti halnya menurut Nidallah (2011, hlm. 5) menyebutkan bahwa "Syarif Hidayatullah adalah seorang penyebar agama Islam di Jawa (Barat) yang terkenal. Kharismanya menembus batas-batas Negara." Sehingga masyarakat akhirnya menjadikan makam tersebut menjadi tempat untuk berziarah dan 
melakukan berbagai aktivitas lain didalamnya. Selain itu, menurut Ruyadi (2010, hlm.581) mengatakan bahwa "kharisma tidak dimiliki oleh orang biasa karena hal itu dianggap berasal dari Tuhan. Atas dasar itu, orang yang memiliki kharisma diperlakukan sebagai pemimpin". Sehingga Sunan Gunung Jati dianggap memiliki kharisma berdasarkan peran beliau sebagai pemimpin dalam pengembangan agama Islam di Jawa Barat.

Dengan keberadaan tradisi ziarah makam tersebut membawa perubahan dalam masyarakat sekitar Makam Sunan Gunung Jati yang berada pada blok Pekauman. Masyarakat Desa Astana memanfaatkan keberadaan tradisi ziarah tersebut sebagai tempat untuk mencari nafkah sehingga terjadilah arus sosial-ekonomi pada masyarakat di sekitar Makam Sunan Gunung Jati yang berada pada komplek blok Pekauman. Blok Pekauman sendiri merupakan salah satu blok di Desa Astana yang terbagi menjadi $1 \mathrm{RW}$ dan $4 \mathrm{RT}$. Namun saat ini setiap harinya RT 2 pada blok Pekauman dipenuhi oleh pedagang yang berasal dari Desa Astana. Aktivitas sosial- ekonomi masyarakat tersebut mengalami perubahan di mana tidak hanya masyarakat dari blok Pekauman saja, tetapi dengan masyarakat lainnya yang berasal dari Desa Astana. Dalam masyarakat, perubahan sosial-ekonomi yang terjadi karena masyarakat sudah menerima caracara hidup baru dengan memanfaatkan makam Sunan Gunung Jati ini sebagai tempat untuk menemukan berbagai peluang usaha. Soemardjan (dalam Setiadi \& Kolip, 2011, hlm 610) menyatakan bahwa "perubahan sosial adalah segala perubahan pada pada lembaga- lembaga kemasyarakatan yang di dalam suatu masyarakat tersebut akan mempengaruhi sistem sosialnya, termasuk di dalamnya nilai-nilai, sikap-sikap, dan pola-pola peri kelakuan diantara kelompok- kelompok dalam masyarakat".

Sehingga

kondisi

sosial- ekonomi tersebut saling berkaitan di mana pada masyarakat sekitar makam Sunan Gunung sendiri kondisi sosialekonomi tersebut akan saling mempengaruhi satu sama lainnya. Seringnya masyarakat melakukan aktivitas perekonomian dengan berdagang, maka aktivitas sosialnya akan terpengaruhi baik itu berupa peningkatan maupun penurunan. Hal tersebut sejalan dengan Todaro (dalam Ayu, Harafah \& Millia, 2016, hlm. 139) yang mendefinisikan bahwa ilmu ekonomi adalah ilmu sosial, ia berkepentingan dengan manusia dan sistim sosial di mana manusia mengorganisasikan aktivitas- aktivitas dalam rangka pemuasan kebutuhan dasar (makan, tempat tinggal, dan pakaian) serta kebutuhan-kebutuhan non materil (pendidikan, pengetahuan, keindahan, spiritual dan sebagainya). (hlm.139).

Sehingga secara umum dapat dikatakan bahwa keadaan sosial- ekonomi suatu masyarakat akan saling bersangkutan antara satu sama lain. Karena dalam kehidupan seseorang di mana tidak dapat dipisahkan antara faktor sosial dan ekonomi, namun faktor sosial tersebut akan menentukan tingkat ekonomi maupun sebaliknya. Terlihat di mana aktivitas sosial masyarakat dalam melakukan tradisi ziarah berdasarkan kepercayaan yang masyarakat yakini hingga saat ini menjadikan kebermanfaat bagi masyarakat dalam bidang ekonomi.

Namun, tetap saja aktivitas dan kepercayaan masyarakat akan tradisi ziarah tersebut tidak mengalami perubahan. Masyarakat sekitar makam Sunan Gunung Jati masih tetap mempercayai dampak positif yang akan dirasakan ketika melakukan ziarah, karena ziarah memang merupakan sunah Rasul yang tetap dijalankan sampai saat ini. Justru dengan adanya tradisi ziarah ini membawa perubahan yang mensejahterakan masyarakat.

\section{STUDI LITERATUR}

\subsection{Perubahan Sosial}

Lauer (1993, hlm. 4) mengatakan bahwa "perubahan sosial sebagai suatu variasi atau modifikasi dalam setiap aspek proses sosial, pola sosial, dan bentuk-bentuk sosial, serta setiap modifikasi pola antar hubungan yang mapan dan standar perilaku". Dengan demikian, bahwa perubahan sosial tersebut benar-benar akan memasuki kepada keseluruhan aspek kehidupan sosial. Di mana kehidupan sosial tersebut secara terus menerus akan mengalami suatu perubahan. Tingkat perubahan dari waktu ke waktu pun akan berbeda tergantung pada kondisi masyarakat.

Hal tersebut diperkuat kembali oleh Lauer (1993, hlm.5) bahwa "terdapat kesenjangan waktu, sehingga perubahan yang terjadi pada satu tingkat lebih lambat disbanding yang terjadi pada tingkat lain. Namun tetap saja perubahan di setiap tingkat kehidupan sosial dianggap sebagai perubahan sosial." dapat disimpulkan bahwa seluruh perubahan yang terjadi dalam kehidupan masyarakat disebut sebagai perubahan sosial, yang membedakannya hanya pada tingkat perubahannya saja. 
Ogburn (dalam Soekanto, 1983, hlm. 100) mengungkapkan bahwa "perubahan pada satu lembaga sosial, akan mengakibatkan terjadinya perubahan pada lembaga-lembaga sosial lainnya. Dia menyatakan bahwa bagian-bagian dari suatu masyarakat saling berhubungan sebagaimana halnya dengan bagian-bagian dari mesin mobil".

Sehingga dalam aktivitas sosial- ekonomi masyarakat tidak terlepas saling keterkaitan di dalamnya. Karena apabila suatu perekonomian menurun atau membaik, akan mempengaruhi terhadap kondisi sosialnya.

Perubahan sosial merupakan suatu proses secara terus-menerus dalam masyarakat sehingga dari waktu ke waktu masyarakat mengalami perubahan, sekecil apapun itu. Namun perubahan sosial yang terjadi dalam masyarakat satu tidak akan sama dengan masyaraat lainnya. Perubahan dalam masyarakat terdapat berbagai ciri didalamnya, hal tersebut seperti menurut Soekanto (dalam Lumintang, 2015) sebagai berikut:

a. Tidak ada masyarakat yang berhenti perkembangannya karena setiap masyarakat mengalami perubahan yang terjadi secara lambat maupun cepat.

b. Perubahan yang terjadi pada lembaga kemasyarakatan tertentu akan diikuti oleh perubahan pada lembaga-lembaga sosial yang lain.

c. Perubahan yang telah berlangsung sangat cepat, biasanya mengakibatkan disorganisasi karena dalam

masyarakat ada proses penyesuaian diri atau adaptasi. Disorganisasi yang diikuti oleh proses reorganisasi tersebut akan menghasilkan pemantapan kaidah-kaidah dan nilai yang baru.

d. Suatu perubahan tidak dapat dibatasi pada aspek kebendaan atau spiritual saja, karena keduanya mempunyai hubungan timbal balik yang kuat. (hlm. 58)

Berdasarkan ciri-ciri tersebut, terlihat bahwa perubahan sosial tidak akan berhenti perkembangannya apabila telah memasuki kehidupan suatu masyarakat. yang berbeda hanya pada tingkat perkembangan perubahan sosial, yaitu akan cepat maupun lambat. Selain itu, perubahan sosial yang dirasakan masyarakat pada satu aspek, akan menyebabkan perubahan pula pada aspek lainnya. Dan bersifat saling mempengaruhi antara satu sama lainnya.

\subsection{Makna Ziarah Makam Wali}

Ziarah makam Wali tersebut yang menjadi daya tarik sehingga banyak masyarakat yang melakukan ziarah terletak pada makna yang terkandung di dalamnya. Makna tersebut dapat berupa simbol-simbol. Simbol tersebut dapat berupa objek, kejadian atau berupa catatan-catatab tertulis yang kemudian dimaknai oleh manusia. Dalam ziarah makam, ritual merupakan suatu hal yang dijalani sebagai aktivitas pada kegiatan ziarah tersebut.

Sutardi (dalam Irmasari, 2013) mengungkapkan bahwa "ritual adalah simbol yang dipakai oleh suatu masyarakat untuk menyampaikan konsep kebersamaan, ritual adalah tempat untuk melebur segala konflik keseharian kepada nilai-nilai spiritual". Ritual dalam ziarah tersebut tidak selalu berupa hal-hal seperti mantra atau dalam bentuk sesajen, tetapi bisa pula dalam bentuk pembacaan doa-doa, tahlil, selawat yang ditujukan untuk mendoakan orang yang dikuburkan.

Hal tersebut diperkuat oleh Yiliyatun (2015, hlm. 346) yang mengungkapkan "sebagian besar para peziarah mengakui bahwa tujuannya berziarah adalah untuk mengenang kembali dan meneladani keshalehan para Wali. Di samping itu juga untuk bertawassul melalui berdzikir, berdoa, dan membaca Al-Quran sebagai bentuk refleksi keimanannya kepada Allah SWT'.

Ritual yang terdapat dalam ziarah makam tersebut yang akan menjadi tujuan masyarakat ketika melakukan ziarah. Tujuan dalam melakukan ziarah tersebut merupakan refleksi dalam kegiatan ritual, di mana tujuan dari melakukan ritual adalah untuk mendoakan orang yang dikuburkan, meminta barakah, karamah, dan sebagainya.

\section{METODE PENELITIAN}

Penelitian ini menggunakan pendekatan campuran (mix method) dengan menggunakan metode deskriptif. Penelitian ini dilakukan pada masyarakat Blok Pekauman Desa Astana yang berada di sekitar makam Sunan Gunung Jati Cirebon. Informan dalam penelitian ini sebanyak 65 orang untuk pengisian angket, dan kepada 5 informan untuk diwawancarai, yaitu masyarakat sekitar makam Sunan Gunung Jati. Pihak-pihak yang menjadi informan tersebut dianggap memiliki pengetahuan dan informasi yang dibutuhkan terkait dengan permasalahan yang diteliti.

Penentuan dari informan ini menggunakan teknik purposive sampling, dan hasil penelitian diperoleh dengan dari hasil angket, observasi, studi dokumentasi dan wawancara. Teknik analisis data yang digunakan adalah analisis data kuantitatif dan kualitatif. Teknik analisis data dalam kuantitatif 
diawali pengolahan data menurut Margono (dalam Zuriah, 2009) dengan menggunakan pengklasifikasian data, koding, dan tabulasi. Setelah itu menggunakan statistika deskriptif dengan menuangkan pertanyaan hasil angket ke dalam rumus prosentase. Analisis data kualitatif menggunakan tiga tahap analisis menurut Miles dan Huberman (dalam Sugiyono, 2011, hlm. 91), tahap awal merupakan reduksi data dengan memilah dan memilih kata yang baik dan benar dari hasil wawancara, kemudian display data dengan merumuskan informasi yang diperoleh dari semua informan, dan yang terakhir penarikan kesimpulan.

\section{HASIL DAN PEMBAHASAN}

Dalam gambaran sosial-ekonomi

masyarakat akan diungkapkan hasil penelitian melalui agket dengan sub- sub indikator yang diteliti. Kondisi sosial-ekonomi tersebut saling berkaitan satu sama lainnya di mana akan saling mepengaruhi. Zunaidi (2013, hlm. 54) mengungkapkan bahwa "sosial-ekonomi merupakan segala sesuatu yang saling berkaitan dengan pemenuhan kebutuhan yang ada di masyarakat atau lebih umumnya terkait dengan kesejahteraan masyarakat untuk melihat kondisi sosial-ekonomi”. Indikator yang diteliti tersebut mengacu pada teori Dove mengenai peran modernisasi dalam kebudayaan. Aspek tersebut berupa perubahan social, agama tradisional, ekonomi, dan lingkungan hidup.

Point pertama, mengenai perubahan sosial. Perubahan sosial yang dirasakan oleh masyarakat di Blok Pekauman desa Astana yang berada di sekitar kompek makam Sunan Gunung Jati diantaranya adalah pendidikan. Pendidikan dinilai penting dan sangat penting bagi kehidupan masyarakat di blok Pekauman. Di mana pendidikan menurut Rijono (dalam Zainuddin, 2008, hlm. 759) mengatakan bahwa "...pendidikan dijadikan sebagai agen perubahan sosial (agen of change) di masyarakat. Dipihak lain, pendidikan juga mempengaruhi perubahan sosial itu sendiri, sehingga keduanya terdapat hubungan timbal balik". Karena dalam perubahan sosial yang terjadi dalam masyarakat, pasti akan saling mempengaruhi antar aspek satu dengan aspek yang lainnya. Terlihat dari hasil angket yang menyatakan bahwa sebagian besar masyarakat menganggap pendidikan sangat penting $(53,85 \%)$, dengan masyarakat mempunyai rencana dalam menyekolahkan anak sebagian besar sampai tingkat Sarjana $(69,23 \%)$.
Hal tersebut sudah terlihat bahwa adanya kesadaran masyarakat bahwa pendidikan pada zaman sekarang ini dinilai penting. Kemudian, pernyataan masyarakat tersebut didukung dengan kondisi pendidikan daerah ini sudah baik $(27,69 \%)$ di bandingkan dulu yang masih biasa saja $(69,23 \%)$. Diperkuat oleh Fathurrohman (2013, hlm. 274) yang mengatakan bahwa "universitas merupakan tempat di mana individu-individu yang menonjol menjalani pendidikan dan latihan, guna mengatasi kemiskinan sumber daya alam dan manusia". Sehingga tak heran saat ini masyarakat sebagain besar menyekolahkan anaknya hingga Sarjana guna untuk mendapatkan kehidupan yang lebih baik.

Dinamika dalam masyarakat berkaitan erat dengan perubahan masyarakat yang terjadi dalam proses interaksi. Parson (dalam Munthe,

2007) unsur-unsur yang terjadi dalam interaksi dan kegiatan masyarakat diantaranya:

a. Orientasi manusia terhadap situasi yang melibatkan orang lain.

b. Pelaku yang mengadakan kegiatan dalam masyarakat.

c. Kegiatan sebagai hasil orientasi dan pengolahan pemikiran pelaku tentang bagaimana mencapai cita-cita.

d. Lambang dan sistem perlambangan yang mewujudkan komunikasi dalam mencapai tujuan. (hlm.4)

Dalam perubahan sosial masyarakat tersebut pun menyangkut aspek-aspek interaksi dan kegiatan masyarakat. Dalam penelitian ini, untuk intensitas pertemuan dalam masyarakat blok Pekauman sendiri tergolong sering $(27,69 \%)$ berbeda dengan dulu yang sangat sering $(41,54 \%)$ dan intensitas kegiatan masyarakat tergolong sering $(33,85 \%)$ berbeda dengan dulu sangat sering (40\%). Keadaan tersebut sesuai dengan pendapat Zainuddin (2008, hlm. 755) yang mengatakan bahwa "perubahan sosial pada dimensi interaksional mengacu kepada perubahan dalam hubungan sosial, yang berkenaan dengan perubahan frekuensi, jarak sosial, saluran, aturanaturan atau pola-pola, dan bentuk hubungan". Di mana dalam frekuensi masyarakat yang bertemu setiap harinya bahkan akan lebih sering dikarenakan semakin banyaknya pedagang yang ada dan waktu berdagang sebagian masyarakat sampai 24 jam sehari. Untuk kegiatan yang dilakukan masyakat setiap hari berupa berdagang, arisan, unjungunjungan, santunan kepada fakir miskin, santunan kepada guru mengaji dan kegiatan rutin yang dilakukan sebagai tradisi masyarakat. Kegiatan tersebut diantaranya, Syawalan, Kliwonan, Sedekah Bumi dan upacara Nadran, dan Mauludan.

Dalam kegiatan besar yang diadakan satu tahun empat kali tersebut, melibatkan masyarakat luar Cirebon yang dating dari daerah- daerah lain. 
Keterlibatan pengunjung atau peziarah tersebut tidak disia- siakan oleh masyarakat sekitar yang menjadi pedagang. Sehingga peluang usaha di daerah ini semakin baik dan semakin menguntungkan masyarakat. Zainuddin (2008, hlm. 754) mengungkapkan bahwa "di dalam masyarakat maju dan berkembang, perubahan sosial dan kebudayaan selalu berkaitan dengan pertumbuhan ekonomi". Lambat-laun persepsi keberadaan peziarah pun semakin meningkat yaitu dianggap sangat positif $(49,23 \%)$ yang dulunya dianggap positif $(44,62)$.

Point kedua, mengenai agama tradisional. Agama tradisional berupa kepercayaan masyarakat terhadap yang dianggap sakral dan telah ada sejak zaman dahulu yang menghubungkan manusia dengan Tuhannya. Boty (2015, hlm. 39) mengatakan bahwa "agama secara mendasar dapat didefinisikan sebagai perangkat aturan dan peraturan yang mengatur hubungan manusia dengan Tuhannya, manusia dengan manusia lainnya, dan mengatur manusia dengan lingkungannya". Sehingga kepercayaan masyarakat terhadap ritual yang ada merupakan perwujudan bentuk hubungan diantara masyarakat dengan Tuhan, dengan masyarakat lainnya di Blok Pekauman maupun dengan peziarah, dan dengan lingkungannya. Kepercayaan kepada ritual-ritual yang ada ketika malam sakral dan malam istimewa, yaitu pada malam Jum'at Kliwon. Untuk saat ini persepsi masyarakat mengenai ritual dalam tradisi Kliwonan saat ini tergolong positif $(43,08 \%)$, apabila dulu tergolong biasa saja $(46,15 \%)$. Karena ritual pada malam Kliwonan tersebut tidak menyimpang dari ajaran agama, bahkan dilakukan sebagai salah satu sunah Rasul dan pembelajaran yang didalamnya mengandung nilai filosofis untuk menuntun manusia dalam menyempurnakan nilai-nilai keagamaannya.

Salah satu ritual tersebut adalah mandi sumur tujuh atau sumut pitu. Sumur tersebut sering digunakan untuk mandi dan berwudu ketika akan melakukan tahlil agar jiwa bersih dan segar. Selain itu, air tersebut banyak dibawa oleh masyarakat luar untuk berbagai tujuan, misalnya untuk kesehatan, mengobati penyakit, dan lain sebagainya. Sumur tujuh tersebut memiliki arti didalamnya yang apabila dipahami artinya dapat menuntun manusia dalam menyempurnakan agamanya. Adanya beberapa ritual tersebut yang merupakan kepercayaan masyarakat merupakan memersatu masyarakat di mana akan semakin kuat hubungan yang terjalin di antara sesama anggota masyarakat. Hal tersebut berkaitan dengan peran agama tersendiri menurut Boty (2015) diantaranya:

a. Peran agama sebagai faktor integratif. Bagi masyarakat berarti peran agama dalam menciptakan suatu ikatan bersama. b. Peran agama sebagai faktor disintegratif. Meskipun agama memiliki peranan sebagai kekuatan mempersatukan, mengikat, dan memelihara eksistensi masyarakat, pada saat yang sama agama juga dapat memecah-belah bahkan menghancurkan eksistens suatu masyarakat. (hlm.46)

Untuk ritual lainnya yang merupakan sunah Rasul adalah Iktikaf, di mana masyarakat saat ini sudah tidak pernah melakukan Iktikaf $(30,77 \%)$ tersebut. Iktikaf biasanya dengan menginap semalaman dengan membaca tahlil, berdoa sepanjang malam diiringi dengan shalat tahajud. Yang terakhir adalah pembakaran kemenyan yang dilakukan oleh sebagian masyarakat, saat ini tergolong tidak pernah $(40 \%)$. Hal tersebut dikarenakan saat ini sebagian besar yang pembakaran kemenyan hanya dilakukan oleh para juru kunci dan beberapa masyarakat. Pembakaran kemenyan tersebut digunakan untuk wangi-wangian disekitar makam dan di rumah masyarakat. Ritual tersebut dijalankan sesuai dengan sunah rasul sehingga persepsi masyarakat mengenai Iktikaf dan pembakaran kemenyan tersebut adalah positif $(43,08 \%)$ karena tidak merugikan dan menurunkan citra masyarakat sendiri. Apabila dulu biasa saja $(30,77 \%)$

Point ketiga, mengenai ekonomi masyarakat. Munthe (2007, hlm.4) mengatakan bahwa "dalam arti yang lebih luas transformasi tidak hanya terjadi pada bentuk luar, namun hakekatnya meliputi bentuk dasar, fungsi, struktur, atau karakteristik suatu kegiatan usaha ekonomi masyarakat". Sehingga dengan semakin baik dan besarnya peluang usaha yang ada, membuat masyarakat semakin bisa menaikan dan mensejahterakan kehidupannya di zaman modern ini.". Terlihat dari sebagian besar masyarakat saat ini sudah memiliki rumah modern secara permanen $(47,69 \%)$ apabila dulu. Semi permanen $(40 \%)$. Rumah modern tersebut sudah menggunakan keramik dan tempok dari batu bata selain itu sudah dimiliki sendiri tidak mengontrak. Kemudian ditunjang dengan alat transfortasi yang digunakan sebagian besar masyarakat saat ini adalah sepeda motor $(69,23 \%)$ apabila dulu masih menggunakan sepeda $(49,23 \%)$. Sepeda motor digunakan masyarakat untuk melakukan aktivitas sehari-harinya apabila ada pesanan yang jaraknya jauh atau untuk menempuh perjalanan jauh.

Selain itu, karena peluang usaha semain besar maka mata pencaharian, masyarakat saat ini adalah sebagian menjadi pedagang $(61,54 \%)$ apabila dulu sebagain besar menjadi buruh $(33,85 \%)$. Di mana pendapatan yang diperoleh antara Rp1.000.000,00 sampai Rp5.000.000,00 perbulan atau pertiga bulan. Untuk pengeluaran sendiri sekitar Rp3.000.00,000 hingga Rp5.000.000,00 perbulan. 
Point keempat, mengenai lingkungan hidup. Sebagian besar masyarakat saat ini, berpendapat lingkungan di makam Sunan Gunung Jati sudah dianggap bersih $(52,31 \%)$ apabila dulu dianggap biasa saja $(55,38 \%)$. Terlihat dari pembersihan lingkungan yang sudah rutin dilakukan oleh masyarakat. Selain itu, pembersihan dulunya hanya dilakukan oleh juru kunci saja, tetapi saat ini sudah ada pembersihan yang dilakukan oleh petugas pembersihan. Pembersihan tersebut dilakukan setiap hari dalam dua waktu, yaitu pagi dan sore.

Dalam melakukan pembersihan, petugas tersebut dibagi menjadi dua bagian, yaitu membersihkan disekitar rumah warga yang berada di blok Pekauman, dan disekitar tempat berjualan dan tempat parkir. Masyarakat setiap harinya membayar 2.000 rupiah hingga 5.000 rupiah tergantung pada tingkat kebersihan yang diinginkan. Untuk rumah masyarakat sendiri ada yang membersihkan secara mandiri tidak mengandalkan petugas kebersihan sehingga tidak membayar iuran kebersihan. Dengan begitu bentuk pemeliharaan yang telah dilakukan oleh petugas dan wong kemit tersebut dinilai masyarakat telah baik $(44,62 \%)$ di mana sampah yang ada tidak akan bertahan selama satu hari. Diperkuat oleh Lailia (2014, hlm.297) yang mengungkapkan bahwa "perubahan dalam kehidupan sosial membuat adanya kerjasama untuk merubah kondisi lingkungan". Yang terakhir mengenai dampak dari keberadaan peziarah terhadap lingkungan saat ini, di nilai biasa saja $(46,15 \%)$ di mana dulu di nilai positif $(47,69 \%)$. Hal tersebut disebabkan oleh kurangnya kesadaran peziarah terhadap kondisi lingkungan di sekitar pedagang. Walaupun sudah ada yang membersihkan, namun peziarah juga harus ikut menjaga lingkungan, dengan tidak membuang sampah sembarangan.

\section{KESIMPULAN}

Gambaran sosial-ekonomi dalam masyarakat Blok Pekauman dikaji dengan menggunakan teori Dove mengenai peran kebudayaan dalam modernisasi. Aspek yang dibahas dalam penelitian ini berupa perubahan sosial, agama tradisional, ekonomi, dan lingkungan hidup.

Pertama mengenai perubahan sosial dalam bidang pendidikan, intensitas pertemuan dan kegiatan masyarakat, dan dampak peziarah terhadap masyarakat. untuk persepsi mengenai pendidikan masyarakat menganggap sangat penting $(53,85 \%)$, di mana sebagaian besar masyarakat mempunyai rencana dalam menyekolahkan anak sampai tingkat Sarjana $(58,46 \%)$. Ditunjang dengan kondisi pendidikan daerah ini yang sudah baik $(27,69 \%)$ berbeda dengan dulu yang masih biasa saja $(69,23 \%)$.

Kedua, mengenai agama tradisional. Kepercayaan kepada ritual-ritual yang ada ketika malam sakral dan malam istimewa, yaitu pada malam Jum'at Kliwon. Untuk saat ini persepsi masyarakat mengenai ritual dalam tradisi Kliwonan saat ini tergolong positif $(43,08 \%)$, apabila dulu tergolong biasa saja $(46,15 \%)$. Untuk ritual lainnya seperti Iktikaf, saat ini masih pernah dan tidak pernah melakukan Iktikaf $(30,77 \%)$. Kemudian adalah pembakaran kemenyan yang dilakukan oleh sebagian masyarakat, saat ini tergolong tidak pernah $(47,69 \%)$. Untuk persepsi masyarakat mengenai Iktikaf dan pembakaran kemenyan tersebut adalah positif $(43,08 \%)$ karena tidak merugikan dan menurunkan citra masyarakat sendiri. Apabila dulu biasa saja $(30,77 \%)$.

Untuk kondisi ekonomi, dibagi menjadi beberapa bidang. Pertama dilihat dari kondisi rumah yang sebagian besar masyarakat saat ini sudah memiliki rumah modern secara permanen $(47,69 \%)$ apabila dulu. Semi permanen (40\%). Kedua mengenai alat transfortasi yang digunakan sebagian besar masyarakat saat ini adalah sepeda motor $(69,23 \%)$ apabila dulu masih menggunakan sepeda $(49,23 \%)$. Ketiga, mata pencaharian, masyarakat saat ini adalah sebagian menjadi pedagang $(61,54 \%)$ apabila dulu sebagain besar menjadi buruh $(33,85 \%)$.

Yang terakhir mengenai lingkungan hidup. Kondisi lingkungan di makam Sunan Gunung Jati sudah dianggap bersih $(52,31 \%)$ apabila dulu dianggap biasa saja $(55,38 \%)$. Dengan pemeliharaan yang telah dilakukan oleh petugas dan wong kemit tersebut dinilai masyarakat telah baik (44,62\%). Sedangkan ampak dari keberadaan peziarah terhadap lingkungan saat ini, di nilai biasa saja $(46,15 \%)$ di mana dulu di nilai positif $(47,69 \%)$.

\section{REFERENSI}

Ayu F.S.K, Harafah, L.O.M \& Millia, H. (2016). Kondisi Sosial Ekonomi Masyarakat di Sekitar Pertambangan Nikel di Kecamatan Bahodopi Kabupaten Morowali. Jurnal Ekonomi, 1(1), hlm. 135-145.

Boty, M. (2015). Agama dan Perubahan Sosial (Tinjauan Perspektif Sosiologi Agama). Jurnal Istinbath, 14 (15), hlm. 35-50. 
Fathurrohman, M. (2013). Pendidikan Islam dan Perubahan Sosial. Jurnal Tadris, 8 (2), hlm. 250279.

Irmasari, M. 2013. Makna Ritual Ziarah Kubur Angku Keramat Junjung Sirih oleh Masyarakat Nagari Paninggahan. E-Journal UNP.

Lailia, A.N. (2014). Gerakan Masyarakat dalam Pelestarian Lingkungan Hidup (Studi tentang Upaya Menciptakan Kampung Hijau di Kelurahan Gunduh Surabaya), jurnal Politik Muda, 3 (3), hlm. 283-302.

Lauer, R.H. (1993). Perspektif tentang Perubahan Sosial. Jakarta : Rineka Cipta.

Lumintang, J. (2015). Pengaruh Perubahan Sosial Terhadap Kemajuan Pembangunan Masyarakat Di Desa Tara-Tara I. E-Jurnal Acta Diurna, 4 (2).

Munthe, H, M. (2007). Modernisasi dan Perubahan Sosial Masyarakat dalam Pembangunan Peranian: Suatu Tinjauan Sosiologis. Jurnal Harmoni, 2 (1), hlm.1-7.

Nadillah, A.G.A. (2011). Mengaji pada Sunan Gunungjati. Cirebon : Zulfana Cirebon.

Ruyadi, Y. (2010). Model Pendidikan Berbasis Kearifan Budaya Lokal (Penelitian terhadap Masyarakat Adat Kampung Benda Kerep Cirebon Provinsi Jawa Barat untuk Pengembangan Pendidikan Karakter di Sekolah). Proceedings of the 4th International Conference on Teacher Education; Join Conference UPI \& UPSI Bandung, Indonesia.

Setiadi, E. M \& Kolip, U. (2011). Pengantar Sosiologi. Jakarta : Kencana Prenada Media Group.

Soekanto, S. (1983). Teori Sosiologi tentang Perubahan Sosial. Jakarta : Ghalia Indonesia.

Sugiyono. (2011). Metode Penelitian Kombinasi (Mix Method). Bandung : Alfabeta.

Yiliyatun, Y. (2015). Ziarah Wali sebagai Media Layanan Bimbingan Konseling Islam untuk Membangun Keseimbangan Psikis Klien. Jurnal Bimbingan Konseling Islam, 6 (2), hlm. 335-354.

Zainuddin. (2008). Perubahan Sosial dalam Perspektif Sosiologi Pendidikan. Jurnal Religia, 7 (3), hlm.750-766.

Zunaidi, M. (2013). Kehidupan Sosial Ekonomi Pedagang di Pasar Tradisional Pasca Relokasi dan Pembangunan Pasar Modern. Jurnal Sosiologi Islam, 3 (1), hlm. 52-64.

Zuriah, N. (2009). Metodologi Penelitian Sosial dan Pendidikan. Jakarta : Bumi Aksara. 